\title{
Editorial
}

\section{Why is the Relationship Between Philosophy and Literature of Significance for the Philosophy of Education?}

\section{LIAM GEARON AND EMMA WILLIAMS}

\section{PROLEGOMENA}

The Road is a post-apocalyptic novel of gargantuan vision framing an American landscape where a father and a son roam a country devoid now of civilization or culture or kindness, where now rule the antitheses of mayhem, anarchy, cruelty and cannibalism, where amoral bands wander in search of human meat. The father and the son, the only two truly moral characters in the novel, hold a metaphorical light to the dead and deadening landscape of an America wrecked beyond recognition by an unspecified catastrophe. Written in simple prose by the American writer Cormac McCarthy - an author renowned for narratives of the American west (The Border Trilogy) and the terrible, detached violence of the American city (No Country for Old Men) - The Road takes us with father and son through this landscape. There is good reason, no good argument, why the father feels the need to encourage the son, following the father's death, to carry still the light in this hell. And yet, likely for most readers, not only the light but the lives of these characters tell us too to carry what light we have. And we finish our reading of the novel — it is a novel, it is a made-up story, the world is not yet like that-perhaps also inclined for a while to carry the light.

This is of course but one reading, perhaps naïve, even a sentimental reading, but for these readers a satisfying one. Between the layers of historical and postapocalyptic critique, we see in this novel a story of education in the most basic sense, a drawing out, a drawing along, an uncertain leading towards the uncertain destiny which is the future and the striving to find human purpose.

One of the great lessons from dystopic fictions, the great lesson from dystopia, is the vision of what we and our societies might be, spoken, written in language which is not technical, which is accessible, which uses prose to share feelings and ideas and situations of the future which help us prepare our days in the present. The famous ending to H.G. Wells' The Time Machine - an extraordinary narrative by a former teacher of science, himself once taught by 'Darwin's Bulldog' T.H. Huxley-is in essence a Victorian drama of middle class men, and the journey of one of them to a future where a privileged class of enervated dwellers in the light are fed and housed by slavish dwellers of the underground and the darkness. It is a socialist tale, as befits (the albeit rather idiosyncratic) socialism of the science fiction writer, like many intellectuals a Communist fellow traveller in the 1920s and 1930s, a man who met Lenin, whose post-Revolutionary Soviet Minister of Education Anatoly Lunacharsky facilitated Wells' visits to new Soviet schools (where Wells was lauded as highly as Shakespeare)-Wells' Russia in the Shadows is a must read for anyone not familiara man who in 1934 met and interviewed Stalin, a writer who believed in eugenics with more openness than some Nazi ideologues in the course of his 1940s work 
Rights of Man. A man and a writer, then, of problematic political pedigree who nevertheless authored highly popular histories of the world for the purposes of public education. We can see all of this as-yet-to-happen history when we read the ending to a novel published in the last years of the nineteenth century. The ending to The Time Machine, rarely glimpsed in Hollywood versions, is set several hundred thousand years in the future, where the time-traveller lands to see that all that is left of the comfortable middle-class world of late Victorian England is a sky with an enlarged, giant red sun, and a beach, all that is left of humanity and civilization, is that beach inhabited by large crabs scuttling across the sand.

If philosophy, and perhaps above all, philosophy of education is there to help and open up the processes of thinking about the world, one wonders why its efforts are lesser known and read than the sorts of books just mentioned, the novels. Any reader of this Editorial would of course have other choices of author. But it is a thought-provoking notion why, compared to literary authors, philosophers of education hold lesser sway on the popular mind-set. Indeed, it sometimes seems that the more common, or more renowned, is the exemplar from literary fictions the more effective is the point made. By literary fiction is meant here the sort of fiction which provokes thought about the world and is not merely written to entertain-despite the democratisation of the arts and literature there is still an important distinction here. And we might thus draw into discussion a book like 1984, another made-up story or novel about an anonymous and oppressed individual called Winston Smith who meets Julia, and whose mutual love momentarily wards off the intrusions of the all-powerful totalitarian State. Though difficult naturally to quantify - a notional measurement on which so many judgements of 'evidence' in educational research are based-1984, a made-up account of a political world in which the all-powerful seems to win, had far more influence in the world of Cold War and post-Cold War politics than any tract of political theory, let alone any text of philosophy of education. Yet 1984 portrays the crushing power of the all-powerful State as in the end morally bankrupt, in a sense therefore the loser in the ethical evaluation of the text. Winston and Julia win because we love them more as characters than we do the character of the State. Following their extended 'interrogation', the intensively torturous re-education to ensure doctrinal purity, the two broken figures meet in the Chestnut Tree Café. They declare they have each betrayed each other ('Under the spreading chestnut tree / I sold you and you sold me'). Yet we do not blame them for a failure to resist torture just as most people do not sympathise with bullies, personal or collective. The novel ends with a seeming victory of consciousness of State over individual, Winston

'... gazed up at the enormous face. Forty years it had taken him to learn what kind of smile was hidden beneath the dark moustache. O cruel, needless misunderstanding! O stubborn, self-willed exile from the loving breast! Two gin-scented tears trickled down the sides of his nose. But it was all right, everything was all right, the struggle was finished. He had won the victory over himself. He loved Big Brother' (Orwell, 2004, p. 274).

The last four words of this last final paragraph of 1984 should give us hope, though what we confront today is a reality in which the mass of populations succumb to the love of big brother, where knee-jerk political sympathies are the norm, where an issues-based raft of ideologically driven causes are forwarded-in politics as in education - under the guise of a formless, progressive liberalism, that seems to mean 
little in actuality, which frames the consciousness of young minds with every bit of effectiveness as the ideology of Oceania, and as England had become in 1984, Air Strip One.

Education it seems has, for whatever reason, a confining, a stultifying and siloenacting impact, as if the very thought of classrooms brings to the subject the same closure and enclosure. Yet beyond the writers of fiction listed, think of philosophers the like of Isaiah Berlin or Karl Popper or Hayek - to list those even writing at the time of Orwell - and we do see an impact on the world described and interpreted.

We attempt here, then, to return philosophers of education to a breadth we consider the field to have lost - or perhaps undervalued. Our method is to introduce the term literature to the already interdisciplinary practice of philosophy of education. Our aim is simple, and yet likely to be considered overly ambitious: to draw philosophy of education through literature to a widening up not a narrowing of hermeneutical horizons. Our premise begins with a remembering of fundamental and yet, we perceive, too often forgotten principles. We seek a beginning here-and like undergraduates we may well suffer from the charges of thinking too largely, too holistically.

We think the risk is worth taking. So philosophy in its original terms concerns philosophia or the love of wisdom. The thinking about thinking makes, has always made, philosophy a metaprocess. Its applications have been and remain concerned with all branches of human knowledge--science, the arts, humanities, literature, religion--and philosophical thinking is therefore unlimited except by self-imposed restrictions or when knowledge - as in the sciences, think of Stephen Hawking's claim that 'philosophy is dead' - precludes philosophers from meaningful discussion. In his day Aristotle could afford to go on to write Metaphysics directly after Physics, to pen the Poetics as easily and with the same authority as the Politics. Philosophers, except specialists within disciplines, cannot do this. And in education, they have been squeezed by the social sciences, by the emphasis on the need to demonstrate rigour in methods. It is perhaps for this reason that philosophers of education have become in recent decades a degree defensive, and sometimes this defensiveness can result in turning inward, barricading our ideas in specialised debates, guarding our thoughts in a language of technicality (we do not see ourselves as being outside of this fate).

Yet philosophy as a discipline also has the capacity to reflect on its own conditions: to think about what its current practices, methods, aims and purposes allow thinking to become - and what ways of thinking it is closing down. Our own reflections along this path draw us to another more generally accessible area of thought. Here we reflect on our own antecedent motivations, those drives which led us, prejudicially, or by reason of the influences of our own lives, our personal inclinations, to books, stories, novels, and to recognise from our lives how-see the example above. We may conclude that we have learnt to know most profoundly about the world from sources which seem very philosophical indeed, in the sense of being thought-provoking, but which are not apparently in any strictly technical, perhaps not even allowable sense, philosophy.

\section{ANTECEDENCE}

All research is inspired by antecedent motivations. Ours is making sense between disciplines and cross disciplinary interests, which have ranged across the study of philosophy and literature in, but not limited to, formal educational contexts. Our framing encompasses both the formal situatedness of learning in schools and 
universities, but is also cognisant of the wider areas and contexts of intellectual formation. Our previous work has, for example, incorporated analyses of the textual forms of a range of disciplines, from works of traditional philosophy, and close readings of diverse literary, political and theologicalcanons (Gearon, 1999; 2002; 2015a; 2015b; Williams, 2016).

Our interests extend also towards cultural storehouses and sources of cultural production, where definitions of value in artefact and literary production are made public in spaces which our society defines as archives, galleries, libraries, museums, and other centres of what are in essence centres for the education of the public in what is culturally important and significant. Wider framings of education we consider often seriously neglected in thinking about education. In other words, schools, universities and other formal institutions of learning are not the only repositories of the culturally formative. Of course, our treatment in this Special Issue cannot hope at this stage to fully treat of all the complexities of power and influence that lie behind the cultural realm in its formal and informal settings. This is a task that is inherent in our investigation and a call for further collaborations in the future-with sub-disciplines including aesthetics, cultural studies, critical theory, educational sociology and global humanities. Our research goals are thereby ambitiously conceived, as are our pedagogical intentions. We seek to encourage a conversation of ideas and facilitate thinking on the possibilities of reciprocal learning in and between different disciplines, but also withthe commercial who have considerable power as shapers and influences of the humanities today. The power of such institutions to define what is good or not good, of value or not of value, is bound we feel to play a far more significant role in the formation of minds than is currently attended to within philosophy of education.

Yet the vision presented so often for us by educationalists within the usual disciplinary perspectives appears to us to present a limiting of the horizon, the implications of this educationally are a constriction and, if done consciously, a restriction, of the possibilities of education itself. The limiting of education here also applies to the research and the search for knowledge. The search for knowledge conceived of, framed and executed, as the search for empirical detail can foreclose and limit the epistemological frame.

\section{WHAT IS AT STAKE HERE?}

In seeking broader precedents for our aims and approaches, we turn and draw attention to works - themselves ambitiously conceived - in which the humanities are explored as a collective. The fate of the humanities is indeed a pressing educational question today, but the history of and question of the humanities extends far beyond literature in the contemporary field of education. This reaches to philosophers, political thinkers, writers and artists - from Victorian to Romantic to Classical periods of history: the contemporary scene of 'humanities advocacy' has similar levels of interdisciplinarity. It is surely a sign of a decline in our educational thinking and institutions (reflecting more widely a decline in human culture) that the humanities are now in a position where they are called to justify their place in the curriculum, in the light of an increasing predominance of STEM subjects (science, technology, engineering and maths). The fault lies not so much with the sciences-which have undoubted importance and value to contemporary human life-as in our drive to conceive academic disciplines in terms of specialisations and technical procedures. For these lead to instrumentalist ways of thinking, which cover a more holistic and 
even existential conception of academic disciplines including their aims and purposes. It limits adequate understanding of the interrelations between subjects: of what the notion of 'interdisciplinarity' - a term much exalted in universities today-might itself mean, and become.

Of course, educational research today is largely dominated by the methods and approaches of the (social) sciences. Historically, there has been antagonism between the 'two cultures' of sciences, and arts and humanities. Yet the humanities as a collective and the social sciences as a collective are subject to self-doubt, and the need for perennial self-justification ever more accentuated by socio-political pressures on university academics and others to produce knowledge that is socially useful and impactful. Our aim then is not to accentuate or exacerbate what may already be seen as a 'two cultures' divide within educational research. What we seek is rather prominence for arts and humanities approaches in educational research. Through a reconsideration of the relationship between philosophy and literature, we aim to show how arts and humanities approaches have the capacity to raise critical methodological and epistemological questions about what educational research today can become.

A limitation is the seductive milieu of interdisciplinary study: its possibilities seem rich but the practicalities of enactment are often frustratingly problematic. There are many reasons for this, lack of expertise, depth of knowledge, genuine collaboration and so on. After all the notion of a 'field' in academic enquiry, originating within a pastoral context, and is an area (a field) defined by boundaries, fences, constraints. Its acreage and extent upheld by law and statute, the space of the field is guarded against intrusion and incursions to other fields are regarded with reciprocal hostility.

Thomas Kuhn's influential work introduces the notion of the paradigm shift. Our problem is what would represent an advance in knowledge for us? If we are looking for new knowledge, what would it look like? We embrace these questions. If there are any lessons from dystopia, the future for humanity, let alone of the humanities, is bleak. Yet we should give credit to philosophy and to literature whose combined educational purpose is a great creative and positive force. Philosophy and literature both help us at the most fundamental level to have a deeper understanding of our place in the world in the short frame of a finite lifespan. These existential questions, sometimes parodied by apparently serious thinkers, rightly preoccupied and gained enormous public popularity for philosophy in the $20^{\text {th }}$ century by their engagement with questions of life, being and meaning which are of real and genuine importance to everyone, not simply academic philosophers. Ours is an attempt to embolden philosophers of education sometimes to enter unknown territories or fields, to take risks at incursion, and though it may appear uncomfortable at times, to welcome intruders and apparent strangers who in the end may be more kindred in aims and outlook ...

\section{CONTEXTS AND INFLUENCES}

In 2015 Liam Gearon and Emma Williams received a Large Grant from the Philosophy of Education Society of Great Britain for a Seminar Series on Philosophy, Literature and Education. This resulted in three seminars: opening at Harris Manchester College, University of Oxford (December 2015), a second seminar at the University of Warwick (February 2016), and a closing seminar at the British Academy, London (May 2016). This Special Issue is an outcome of that programme of collaborative work, which brought together leading and next generation thinkers in 
the fields of philosophy and literature, and philosophy of education, both in the UK and overseas. We note here our gratitude for genuine enrichment from the participants in the programme thus far.

Our Special Issue has long had the aim of giving prominence to, and extending, work in the philosophy of education attentive to questions of literature and literary experience (see for example Buganza, 2012; Carr and Davis, 2007; Cigman, 2014; Conroy, 2004; Davis, 2011; Johansson 2011; Mahon, 2016; O’Donnell, 2014; Smith, 2008, 2010; Standish, 2007, 2015). Yet as well as this we have wanted to give due attention to the rich and often un-mined possibilities for educational thinking in the field of philosophy and literature. In reviewing prominent major collections within philosophy and literature (for example, Carroll, and Gibson, 2016; Cascardi, 2014; Eldridge, 2013; Hagberg and Jost, 2015; Howatson, 2013; John and McIver Jopes, 2004; Rudd, 2010; Russell and Winterbottom, 2008), we find that philosophical questions asked of literature are permeated with educational directions and dimensions. We wanted to provide a platform that would draw attention to this, and thus open up new discussions and overlaps between the fields of philosophy and literature, and philosophy of education. It is for this reason that our Special Issue includes, and sets side by side, contributions from internationally renowned scholars philosophy and literature as well as leading and early career contributors from the field of philosophy of education. Our intention is that this will help to open a new set of dialogues between these fields, with the aim of further enriching and extending research into education today.

One important consideration in the development of our project has been the nature, extent and limitations of interdisciplinarity in shaping perceptions of education in an historical and contemporary socio-cultural and political perspective. This is highly pertinent to parallel debates about the aims and purposes of educational research, including its relationships with the broader social, cultural and political networks in which it has developed (see for example McCulloch and Cowan, 2017). The special relevance and potential that the critical examination of writers embody for the academic discipline of education is demonstrated in the wave of new forms of advocacy for the significance of disciplines of writing that often include an explicit link to the role within lifelong learning and non-institutional forms of education (for example, Collini, 2016, 2017; Phillips, 2017; Small, 2013; Levenson, 2017). Thus our methodology is collaborative and reflective of the rich, often un-mined possibilities of a field to be mapped, defined and analysed by extending cross-disciplinary boundaries of conceptual, philosophical and theoretical knowledge in educational research.

It is within this broad remit, that our lead question is intended to provoke engagement on a number of levels. If the papers gathered together here are anything to go by, there is a tantalising array of possibilities. Nevertheless, the presented assemblage philosophy, literature, education is diverse and, at times, diverging. We have purposively designed this to be so. In preparing the Special Issue we have been especially cognisant of different ways in which the dialogue between philosophy and literature can be explored. We do not seek here to pronounce on correct approachesnor is our aim to entrench divides between 'analytic' and 'continental' styles of philosophy and philosophy of education. Our contributors are representative of the different ways in which the intersection of philosophy and literature opens new possibilities for debate in the philosophy of education. Our aim for the Special Issue has been to 'map the field', to be developed into more specialised avenues in future work. 


\section{CONTRIBUTIONS, THEMES AND OPEN CONCLUSIONS}

Are readers surprised that we have not so far made explicit mention of 'the ancient quarrel' in our editorial? Certainly this phrase, and its immortalisation in Plato's Republic, is perhaps the perennial way of opening the question of the relationship between philosophy and literature. But have Plato's concerns, and his own ways of invoking the question of this relationship, been remote from our discussion hitherto? Republic is itself a work concerned with the nature of the polis and the ideal society: it is a utopia. Plato's examination of this includes a consideration of the kinds of structures and institutions, including systems of education, which would be found within the good city. Moreover, Plato shows us how these social and political issues inevitably extend towards questions of the nature of the human being and the good life, questions that are themselves inextricably linked to what ways of thinking and knowing the world are possible for the human being and within a human life. We find in Plato, then, a holistic intertwining of questions of politics, ethics, reason and knowledge. The question of the relation of philosophy and literature has thus never just been an abstraction of academia. Neither is it well understood as simply a specialist branch of philosophy (one confined to the field of aesthetics, for example). In its own philosophical pedigree, the ancient quarrel is embedded within questions of formation, formal and informal, institutional and extra-institutional - in short, in questions of education.

It is in light of these considerations that we begin our Special Issue with papers that, in differing ways, demonstrate how to consider the relationship between philosophy and literature is not only to make a foray into a branch of philosophy called 'aesthetics', but is rather to examine the very nature and conditions of human thinking, reasoning and expression itself. Our initial group of papers is thus somewhat provocatively titled Literary Philosophy. In 'The Ancient Quarrel and the Dream of Writing', Richard Smith invites us think again about Plato's role in our understanding of disciplinary identities and the forms of reasoning they enshrine. More particularly, Smith demonstrates how the assumed binary between poetry and philosophy itself dissolves when one pays better attention to the letter and narrative framing of Plato's own texts. Smith's paper results in a challenge to a literalistic reading of Republic and other Platonic dialogues, and the hubristic tendencies that stand behind such readings in education as well as in philosophy. Paul Standish's paper on 'Rigour and Recoil: Claims of Reason, Failures of Expression' similarly beings with the 'ancient quarrel', but Standish also leads us through the ways this split has resonated and been exacerbated across this history of philosophy. Standish, like Smith, wishes to unsettle what is too often in philosophy (and education) assumed to be a settled binary between philosophy and the 'literary', reason and emotion, plain language and poetic whimsy. Standish's discussion seeks to reveal an internal connection between certain aspects of language that philosophers seek to set aside, showing how the repression of poesies delivers, neither rigorous thinking nor nuggets of truth, but failures of expression. Conceptions of language are also explored in Emma Williams's paper, which opens the question of how the work of Nobel Prize winning yet 'questionably literary' novelist J.M. Coetzee is open to exploration in relation to education. Coetzee's literature has drawn the attention of a number of philosophers in recent years, predominantly in relation to questions of moral philosophy. Given this, it is perhaps unsurprising that we find Coetzee's work being discussed by a number of contributions in this Special Issue. Paul Standish draws on Coetzee's Elizabeth Costello to explore the centrality of style and form to reasoning itself. Emma Williams' paper on 'Language's Grace: The Redemption of Education in J. M. 
Coetzee's Disgrace' draws on Coetzee's Booker Prize winning novel Disgrace. Tracing the scenes of education that unfold in Coetzee's novel under the sign of 'the great rationalisation', Williams brings out the way that education is portrayed as being in a state of degeneration. By exploring the flickering moments of redemption that are also to be found in the novel, and how we can make sense of them through an alternative conception of language, Williams' paper also suggests that Coetzee's novel indicates ways of thinking that hold possibilities of redemption. Hers is a discussion that draws on Coetzee's literature to raise questions about the legitimate ways of philosophising about education, and it leads to the conclusion that education (and perhaps philosophy) needs to recover its grace.

The papers that comprise our opening section raise questions about the inevitable turning of philosophy to literature in their disciplinary enterprises; our second section collects together papers that demonstrate how literature can enrich and broaden the scope of specific philosophical fields and educational problems. Learning from Literature draws together a series of reflections on literature's role in ethical, moral and political education. The paper that transitions us to this theme is by Eileen John, which further exemplifies the significance of both Plato and Coetzee to our themes. John's paper is entitled 'Allegory and Ethical Formation: Stories for People Who Know Too Many Stories.' Here, she responds to a chapter on the role of stories in Republic by Jonathan Lear. Lear, himself attentive to the literary aspects of Plato's work and thus also contesting the 'literalism' in philosophical interpretations of the claims made for art and poetry in Republic, claims that stories can be ethically formative - rather than coercive - when they subvert their own claims to knowledge. John's paper contests what seems to be an undue limitation on stories in relation to ethical formation by Lear, and draws on the impure allegories of Coetzee and Erpenbeck to reveal richer ways in which stories might be inherited during childhood. John's discussion invites us to consider the power and mystery of stories, alongside their potential to unsettle, as reasons for according them a morally constructive role. It is the genre of fiction and stories best suited to the aims of political education that is the topic of Christine Sypnowich's paper on 'Lessons from Dystopia: Critique, Hope and Political Education'. Sypnowich argues against contemporary political philosophers who dismiss utopian visions as authoritarian and unrealistic. She calls for a re-appraisal of the power of utopian fiction, making use here of a reading of Zamyatin's We. Her paper affirms the importance of hope as a political emotion, and the role of the imagination in political thinking. David Bakhurst's 'Practice, Sensibility and Moral Education' likewise defends the value of literature for moral education. However, Bakhurst offers a new take on the much-stated connection between literature and the moral imagination by elucidating the philosophical picture of the moral life presented by the philosophy of John McDowell and David Wiggins. Bakhurst's discussion invites us to re-think the limiting nature of moral philosophy that is dedicated to systems building and the discernment of principles. Like Wiggins, and Iris Murdoch, Bakhurst explores the role of ethos and vision in moral thinking, and suggests that it is in relation to this that we might better understand the role of literature in the cultivation of moral education.

Our third group of papers to some extent reflect on moral, political and ethical education, but they also present broader arguments for the importance of literature in education. The first paper in the Literary Education section is 'Resonance, Response, Renewal: Literary Education in Rorty and Cavell' by Ánie Mahon and Elizabeth O'Brien. Their paper compares Richard Rorty and Stanley Cavell's ways of reading and responding to literature. Mahon and O'Brien draw attention to Rorty's conception 
of the transformative power of literature, but they also argue that Stanley Cavell's reading of literature offers a richer form of engagement. Cavell, they argue, leads us to see how literary education can be a way in which human beings develop the kinds of sensitivities and responsiveness that they need in their lives together. Different practices of reading literature are also examined in Michael Bell's discussion of 'Aesthetics and Value in Literary Education: Reflections on F.R. Leavis'. Leavis's approach to the education of literature may be less fashionable today, but Bell draws attention to the link between Leavis's approach and the German tradition of aesthetic thought developed by Kant, Schiller, Nietzsche and Dilthey. At stake here is the way that education in literature invites us to reflect on questions of value, and their centrality to the human being and human thought. Anthony J. Cascardi's paper on 'Literary Education in a Free Society' begins with a call for literary educators to better articulate the importance of what they do. Cascardi charts the historical emergence of models of Higher Education, and the place of literature within these models. His paper offers a broader account of the reasons why literature has long been considered as a repository of cultural and moral values - highlighting the connection between literature and philology, and the links this draws between literature and nationalism. Cascardi's paper also invites us to adopt a richer perspective on the relationship between literature and cultural values, based on a notion of 'general education', and the gaining of 'knowledge through' (as opposed to 'knowledge about') literature. This shows how literature can be connected to practical wisdom, and to the cultivation of precisely the kinds of capabilities that human beings need in a 'free society'.

The framing of the purposes of a literary education in relation to the nature of society of course provoke multiple and highly contested reactions in relation to the wider social and political purposes of writing literature, and perhaps even writing philosophy. Regardless of style or form, there is no material manifestation of the aesthetic which is not part of what Jameson defined as 'the political unconscious'; such politically sharp interpretive framings being part of a very modern tradition of aesthetics and politics (for example, Adorno et al., 2007; or Debord, 1984), within resonances of the crisis of the arts in the age of the machine defined by Walter Benjamin's (2008) The Work of Art in the Age of Mechanical Reproduction or Baudrillard's (2005) The System of Objects. So too Fredric Jameson (2002) declares in The Political Unconscious that the aesthetic narrative is a socially symbolic act which constructs social reality. Narrative forms are thus mirrors of more complex constructions.Thus Jean-Francois Lyotard (1984) details how the postmodern, superseding a confidence in the modern and rational means in effect (to put it negatively) the end of the grand narrative or (to put it more positively) the flourishing a fragmentary richness of individual life stories. As the contrasting $19^{\text {th }}$ and $20^{\text {th }}$ century accounts of the role of culture (a term subsuming philosophy, literature and their educative purposes), the respective works of Matthew Arnold's Culture and Anarchy (western culture as bastion against barbarism) and Edward Said's (1994) inverted Culture and Imperialism (western culture as purveyor of barbarism) show, the colonial and post-colonial transformations between these two centuries reaching into our own century mean that literature - the stories we tell-is among the most contested areas of human life, and perhaps among its most important. In this context, we might therefore be wary of educational attempts to construct a unified and educationally 'acceptable' narrative in the light of modern, $21^{\text {st }}$ century literary problems, that is, by putting literature to work simply, narrowly to political ends through literature. 
We see the prominence of this in a recent article in the Harvard Educational Review, where Suzanne Choo (2017) argues for a 'cosmopolitan ethical criticism to the teaching of literature', effectively putting literary works to the service of political goals in the light of modern problems, where 'global risks such as terrorism, fundamentalism and xenophobia permeate our everyday consciousness' impel educators, she argues, 'to cultivate in their students a cosmopolitan hospitality toward multiple and marginalized others in the world', thereby 'developing students as global ethical thinkers' (Choo, 2017, p. 335). Literature put in the service of worthy causes sounds wonderful but there may be only a little epistemic journey between that and the social constructionism of the arts lauded by Stalin when he declared that artists of all hues should be 'engineers of the human soul' (Garrard and Garrard, 1990).

If in sum, the literary and political can be shown to be not only of aesthetic contention but a function of political contestation, then it is with some justification that the final section of this Special Issue examines the political and security contexts of Literary Lives. Here Liam Gearon and Marion Wynne-Davis's 'Literature and Security: CIA Engagement in the Arts-What Philosophers of Education Need to Know and Why' provides a provocative exemplar of the lesser known engagements between the Central Intelligence Agencies and some of the major literary artistic endeavours of the $20^{\text {th }}$ century. Expansively drawing on newly uncovered archival evidence of CIA involvement, they explore the under-examined relationship between literature and security. With both researchers having had substantial and sustained access to the Ransom Humanities Center Special Collections at the University of Texas at Austin, they provide some insights into the possible application of archival research methods. Their particular analysis is through the case study of the worldwide association of writers known as PEN International, and here they provide sufficient material evidence to argue that the CIA engagement with the arts during the Cold War extended to some fairly close dealings with high profile personnel within International PEN. Their broader argument is that the state security engagement with the arts and literature is an important exemplar of what might be positively termed public education by political, often covert means, which might alternatively and derogatively be referred to as propaganda. From the archival evidence arising from CIA engagement with the arts they derive three principles of intellectual framing for analysis of the critical aesthetic of philosophy of education: (1) the political aesthetic of security and literature; (2) cultural citizenship as security; (3) the educational ecosystem of literature as securitisation.

Liam Gearon's 'A Very Political Philosophy of Education: Science Fiction, Schooling and Social Engineering in the Life and Works of H.G. Wells. Literary Lives, Political Philosophies, Public Education' examines the specifics in the life and works of Herbert George (H.G.) Wells' (1861--1946) a still renowned writer of late $19^{\text {th }}$ century science fiction, who was also a one-time teacher of science before fame arrived with the successful publication of his two most notable dystopian 'scientific romances', The Time Machine and War of the Worlds. Gearon's article further explores though the lesser known political writings and educational preoccupations of this famous writer, notably, for the purposes of this Special Issue delineating 'a very political philosophy of education', one which readers may find as shocking as they do surprising. This article argues that Wells' science fiction and subsequent political engagements are a continuum expressed by an imperative: that human history is held 'between education and catastrophe' (Wells, 1938), and that the life and work of a politically unfashionable but still popular writer of science fiction are also a 
masterclass in establishing the critical importance of the interface of literature and political philosophy in education.

We might close with a rhetorical question, as Karolides et al.'s (2011) survey of books banned across the centuries powerfully begs us to ask: why have works of both literature and philosophy and indeed education been banned, censored and burned, not for decades, but centuries? Certainly, it is not because such works are mere pastimes and frivolous luxuries that human beings occasionally engage in - but philosophy, literature, and the humanities in general, are often cast in such unimportant and inessential terms today, with fatal consequences for the way they are positioned in education. But perhaps there is another-though not totally distinct-question we might pose at the close of this editorial: Why, if literature is such a different enterprise to philosophical enquiry, have philosophers felt the need to assert and re-assert this difference, the distinctiveness of philosophical inquiry, and the dispensable role that literature plays within it? Perhaps, as a number of papers in this Special Issue work to show, the individual enterprises of both philosophy and literature are better understood when greater significance is precisely given to the question of their relationship. Moreover, as all papers collected here serve to demonstrate, the question of the relationship between philosophy and literature indeed has import for and can extend our ways of thinking about and in the philosophy of education. Our task has been, and remains, then, to look at the interstitial spaces between the disciplines of philosophy, literature and education, convinced that in these marginal areas of a contested and endlessly defined, ill-defined, and over-defined aesthetic there is a rich intellectual space worthy of investigation in its own right, certainly meriting scholarly and research attention by philosophers, literary scholars and educationalists.

\section{Correspondence:}

Liam Gearon, Oxford University, 15 Norham Gardens, Oxford OX2 6PY

Email: liam.gearon@education.ox.ac.uk

Emma Williams, University of Warwick, Institute of Education, CV4 7AL

Email: emma.williams.1@warwick.ac.uk

\section{REFERENCES}

Adorno, T. W., Benjamin, W., Bloch, E., Brecht and B. Lukacs, G. (2007) Aesthetics and Politics (London, Verso).

Arnold, M. (2009) Culture and Anarchy (Oxford, Oxford University Press).

Baudrillard, J. (2005) The System of Objects (London, Verso).

Benjamin, W. (2008) The Work of Art in the Age of Mechanical Reproduction (London, Penguin).

Carroll, N. and Gibson, J. (eds.) (2016) The Routledge Companion to Philosophy of Literature (London, Routledge).

Cascardi, A.J. (2014) The Cambridge Introduction to Literature and Philosophy (Cambridge, Cambridge University Press).

Choo, S. (2017) Globalizing Literature Pedagogy: Applying Cosmopolitan Ethical Criticism to the Teaching of Literature'. Harvard Educational Review, 87.3, pp. 335-356.

Collini, S. (2016) Common Writing (Oxford: Oxford University Press).

Collini, S. (2017) Speaking of Universities (London: Verso)

Eldridge, R. (ed.) (2013) Oxford Handbook of Philosophy and Literature (Oxford, Oxford University Press).

Debord, G. (1984) Society of the Spectacle (New York, Black and Red). 
Garrard, J. and Garrard, C. (1990) Inside the Soviet Writers' Union (New York, IB TaurisGearon, L. (1999) English Literature, Theology and the Curriculum (London: Cassell.

Gearon, L. (2002) Landscapes of Encounter: The Portrayal of Catholicism in the Novels of Brian Moore (Calgary: University of Calgary Press).

Gearon, L. (2015a) On Holy Ground: The Theory and Practice of Religious Education (London and New York: Routledge).

Gearon L. (2015b) Religious Authority and the Arts: Conversations in Political Washington College Studies in Religion, Politics and Culture, volume 5 (New York: Peter Lang).

Hagberg, G.L. and Jost, W. (eds.) (2015) A Companion to the Philosophy of Literature (Oxford, Wiley Blackwell).

Howatson, M.C. (ed.) (2013) The Oxford Companion to Classical Literature (Oxford, Oxford University Press).

Jameson, F. (2002) The Political Unconscious: Narrative as a Socially Symbolic Act (London and New York, Routledge).

John, E. and McIver Jopes, D. (eds.) (2004) Philosophy of Literature: Contemporary and Classic Readings - An Anthology (Oxford, Blackwell).

Karolides, N. J., Bald, M., Sova, D.B. (eds.) (2011) 120 Banned Books: Censorship Histories of World Literature (New York, Checkmark).

Levenson, M. (2017) The Humanities and Everyday Life (Oxford, Oxford University Press).

Lyotard, J-F. (1984) The Postmodern Condition: A Report on Knowledge (Manchester, Manchester University Press).

McCulloch, G. and Cowan, S. (2017) A Social History of Educational Studies and Research (London, Routledge).

Nussbaum, M. (2010) Not for Profit: Why Democracy Needs the Humanities (Princeton, NJ, Princeton University Press).

Phillips, A. (2017) In Writing (London: Penguin).

Rudd, D. (ed.) (2010) The Routledge Companion to Children's Literature (London, Routledge).

Russell, D.A. and Winterbottom, M. (eds.) (2008) Classical Literary Criticism (Oxford, Oxford University Press).

Said, E. (1994) Culture and Imperialism (London, Vintage).

Swirski, P. (2013) From Literature to Biterature: Lem, Turing, Darwin, and Explorations in Computer Literature, Philosophy of Mind, and Cultural Evolution (Montreal, McGill-Queen's).

Small, H. (2013) The Value of the Humanities (Oxford, Oxford University Press).

Williams, E. (2016) The Ways We Think (Oxford: Wiley-Blackwell). 